\title{
Microstructure and mechanical properties of as-cast and annealed high strength low alloy steel
}

\author{
Bárbara Ferreira de Oliveira ${ }^{1}$, Michel Picanço Oliveira ${ }^{2}$, Luis Augusto Hernandez Terrones ${ }^{3}$, Márcia Giardinieri \\ de Azevedo ${ }^{3}$, Leonardo Barbosa Godefroid ${ }^{4}$ \\ ${ }^{1}$ Higher Education Institute of Censa, Campos dos Goytacazes, RJ, Brazil. \\ ${ }^{2}$ Federal University of Espírito Santo, Jerônimo Monteiro, ES, Brazil. \\ ${ }^{3}$ Northen Fluminense State University, Campos dos Goytacazes, RJ, Brazil. \\ ${ }^{4}$ Federal University of Ouro Preto, Ouro Preto, MG, Brazil. \\ Correspondence: Bárbara Ferreira de Oliveira, Mechanical Systems Analysis and Design Laboratory - LAPSIM, \\ Higher Education Institute of Censa, Campos dos Goytacazes, Brazil. E-mail: barbara.fo@gmail.com
}

Received: July 23, 2019

Accepted: August 7, 2019

Online Published: August 28, 2019

doi:10.5539/jmsr.v8n4p1

URL: https://doi.org/10.5539/jmsr.v8n4p1

\begin{abstract}
This paper presents a study on the microstructure and mechanical properties of a microalloyed HSLA steel solidified by continuous casting process and annealed at $1100{ }^{\circ} \mathrm{C}$ for 1 hour. The techniques of confocal microscopy, scanning electron microscopy and hardness, tensile and Charpy mechanical tests were used. The results of this research showed that the microstructure of the sample in the as-received condition was mainly composed of acicular ferrite and aggregates of ferrite and carbides. Non-metallic inclusion characterization of as-cast steel showed that calcium content was not enough to modify the morphology of some aluminates. After thermal treatment, the initial microstructure was transformed into polygonal ferrite and pearlite. In both conditions, different types of precipitates were found, which were classified according to their distribution in the microstructure. The steel with solidification structure showed a higher tensile strength, but its application would be unlikely in components that require good impact strength.
\end{abstract}

Keywords: microalloyed steel; continuous casting; thermal treatment.

\section{Introduction}

Nowadays, the need of using materials in increasingly hostile environments, such as the exploration of oil in the pre-salt layer, boost the research about microalloyed HSLA (high strength low alloy) steels in order to meet higher safety standards. These materials have microalloyed elements that form carbides, nitrides and also carbonitrides $(\mathrm{V}, \mathrm{Nb}$ and $\mathrm{Ti})$, which act principally to increase the strength through grain refining and can lead to bimodal grain size distribution, depending on the precipitates distribution. The good properties of plasticity and weldability exhibited by these steels are due to the low carbon content ( 0.05 to $0.25 \%$ by mass), ability to significantly reduce the formation of the hard phases responsible for the reduction of toughness. In addition to the above-mentioned elements, these steels have manganese as important alloying element (1-1.7\% by mass) and they may contain small percentages of chromium, nickel, molybdenum, copper, nitrogen and zirconium, which are used in various combinations (Davis, 2001; Kim, 2007; Tisza, 2002).

Most of the world's steel production is solidified by continuous casting. In this process, interdendritic precipitates can be formed and also precipitates in the boundaries of the austenite, that may generate surface cracks in the slabs. Furthermore, formations of non-metallic inclusions may occur, being common to find aluminates and manganese sulphides, as a consequence of the manufacturing process. The formation of aluminates with high $\mathrm{Al}_{2} \mathrm{O}_{3}$ content or $\mathrm{CaS}$ may cause obstruction of the submerged nozzle during casting. As a corrective action, calcium treatment is performed, which functions are to increase melting, minimizing nozzle blockage through the formation of a compound with lower melting point, to improve the machining of the steel and to extend the useful life of the cutting tool (Basanta et al., 2011; Cicutti et al., 1997; Holappa et al., 2003; Turkdogan, 1996; Xu et al., 2018; Wu, 2009).

The addition of calcium to the laddles containing the microalloyed HSLA steels offer a means of reduction the hydrogen induced cracking susceptibility, which is succeeded through preventing the $\mathrm{MnS}$ formation during the 
solidification and modification of the aluminate morphologies, sulphide and silica to globular, since these compounds make this material very susceptible to embrittlement by hydrogen (Cicutti et al., 1997; Turkdogan, 1996; Holappa et al., 2003). With this purpose $\mathrm{Ca} / \mathrm{S}$ ratio must be above 1.5 for steel with sulfur content $>0.001 \%$ (Ghosh et al., 2018).

In this work, a correlation between the microstructure and mechanical properties, as well as the identification of the second phase particles of a microalloyed HSLA steel solidified by the continuous casting process and annealed is made.

\section{Method}

\subsection{Material}

Samples of an HSLA steel (microalloyed) solidified by continuous casting in slab form and with dimensions of $1.2 \times 0.3$ meters were used. The chemical composition of this steel is appropriate to API 5L standard (American Petroleum Institute, 2013) for grade X-70 specification level PSL2 with seam welding, as indicated in Table 1.

The samples for thermal treatments and metallographic analysis were taken from central region of slab with dimensions of approximately $4 \times 1 \times 2 \mathrm{~cm}$. Initially, all planes of samples were studied. After it, the perpendicular plane to the casting direction was studied in detail.

Table 1. Chemical compostion of steel studied (\% by mass)

\begin{tabular}{cccccccccccccccc}
\hline $\mathrm{C}$ & $\mathrm{Si}$ & $\mathrm{Mn}$ & $\mathrm{P}$ & $\mathrm{S}$ & $\mathrm{Al}$ & $\mathrm{Cr}$ & $\mathrm{Ni}$ & $\mathrm{M}$ & $\mathrm{Cu}$ & $\mathrm{B}$ & $\mathrm{N}$ & $\mathrm{Sn}$ & $\mathrm{Ca}$ & $\begin{array}{c}\mathrm{Nb}+ \\
\mathrm{V}+\mathrm{Ti}\end{array}$ \\
\hline 0,06 & 0,28 & 1,53 & 0,016 & 0,0022 & 0,036 & 0,23 & 0,014 & 0,114 & 0,009 & 0,0005 & 0,0045 & 0,002 & 0,0017 & 0,084 \\
\hline
\end{tabular}

A muffle type furnace EDG 3000 was used for the annealing. The heating and cooling rate was $20{ }^{\circ} \mathrm{C} / \mathrm{min}$ and $15^{\circ} \mathrm{C} / \mathrm{min}$, respectively. The treatment was performed at a temperature of $1100^{\circ} \mathrm{C}$ for 1 hour with oven cooling.

\subsection{Microstructure Characterization}

The metallographic preparation followed conventional steps of grinding, polishing and etching with a $2 \%$ Nital solution. Confocal microscope OLYMPUS LEXT OLS4000 and SEM (scanning electron microscope) Shimadzu SSX-550 were used to microstructure characterization. Fifteen images were used to quantify grain size distribution after heat treatment. Identification of chemical constitution of non-metallic inclusions and precipitations of secondary phases located was conducted with the help of EDS (Energy-Dispersive Spectrometry) spectrometer.

\subsection{Mechanical Properties}

All the mechanical tests were conducted at room temperature. To determine the hardness of the material, Shimadzu HMV-2 series hardness tester was used. The load was $2 \mathrm{kgf}$ and the time was 10 seconds. For each condition, fifteen indentations were accomplished in different regions of the samples surface, aiming to reach the largest possible surface area of the samples.

Test specimens and tensile tests were performed according to ASTM E8 (2015) standard in the INSTRON-5582 test machine with a displacement speed of $0.2 \mathrm{~mm} / \mathrm{min}$.

The impact Charpy testing was performed in a Hammer Zwick/Roell RKP 450 impact test machine, following the ASTM E23 (2013) standard in V-notched specimens (CVN $10 \mathrm{~mm} \times 10 \mathrm{~mm}$ x $55 \mathrm{~mm}$ ). After the test, the fracture surfaces of the Charpy specimens were analyzed on Shimadzu SSX 550 and JEOL JSM 7100F SEM.

\section{Results and discussion}

\subsection{As-Cast Condition}

In Figure 1, a three-dimensional assembly revealed a microstructure consisted mainly of acicular $\left(\alpha_{\mathrm{aci}}\right)$, polygonal $\left(\alpha_{\text {poli }}\right)$ and quasi-polygonal and alotromorphic $\left(\alpha_{\text {alo }}\right)$ ferrite. It is also possible to observe the presence of aggregates of ferrite and cementite, non-metallic inclusions and intermetallic precipitates, whose composition was investigated by EDS microanalysis.

Furthermore, the microstructural constituents presented in Figure 2, a smaller fraction of idiomorphic ferrite (aidi) and ferrite with aligned second phase were found. The ferrite with aligned second phase was observed in the form of primary and secondary $\left(\alpha_{\text {wid2 } 2}\right)$ Widmanstätten $\left(\alpha_{\text {wid1 } 1}\right)$ ferrite, precipitated in the boundaries of 
austenite and alotromorphic ferrite, respectively. Babu and Bhadeshia (1991) related that Widmanstätten ferrite is detrimental to toughness, because it tends to grow in a parallel set of plates with the same orientation, which offers low crack propagation resistance.

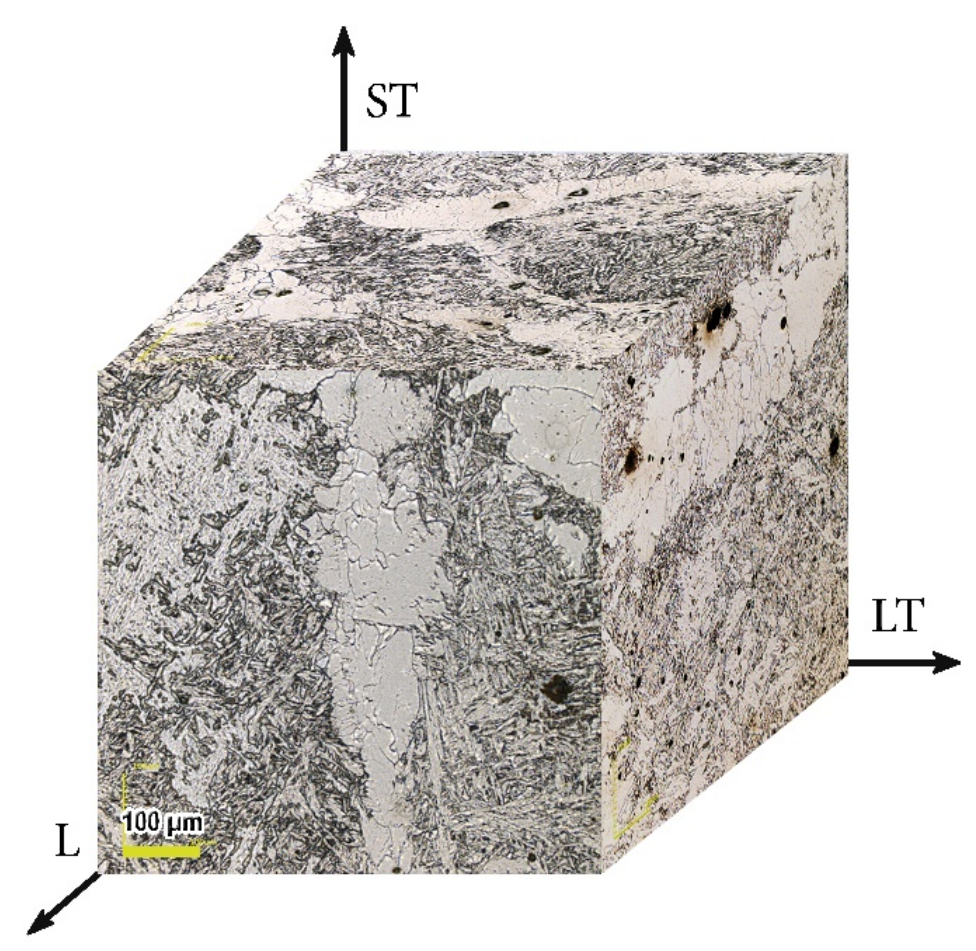

Figure 1. Three-dimensional assembly of the microstructure of as-cast HSLA steel

Figure 2 shows acicular ferrite, that is composed of lenticular plate cross-linked of non-uniform sizes and shapes, and non-metallic inclusions, which, according to Lee et al. (2000), Barbaro (1989), Loder et al. (2017) and Zhao et al. (2018), may favor the nucleation of this phase.

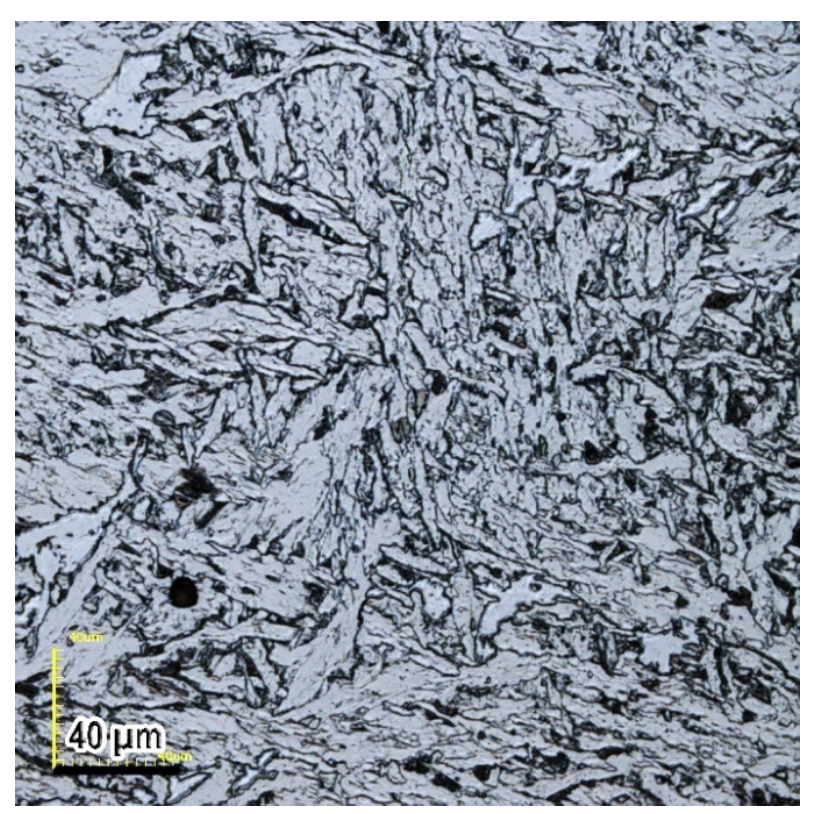

Figure 2. Micrograph of the material in the as-cast condition showing the appearance of the acicular ferrite. 


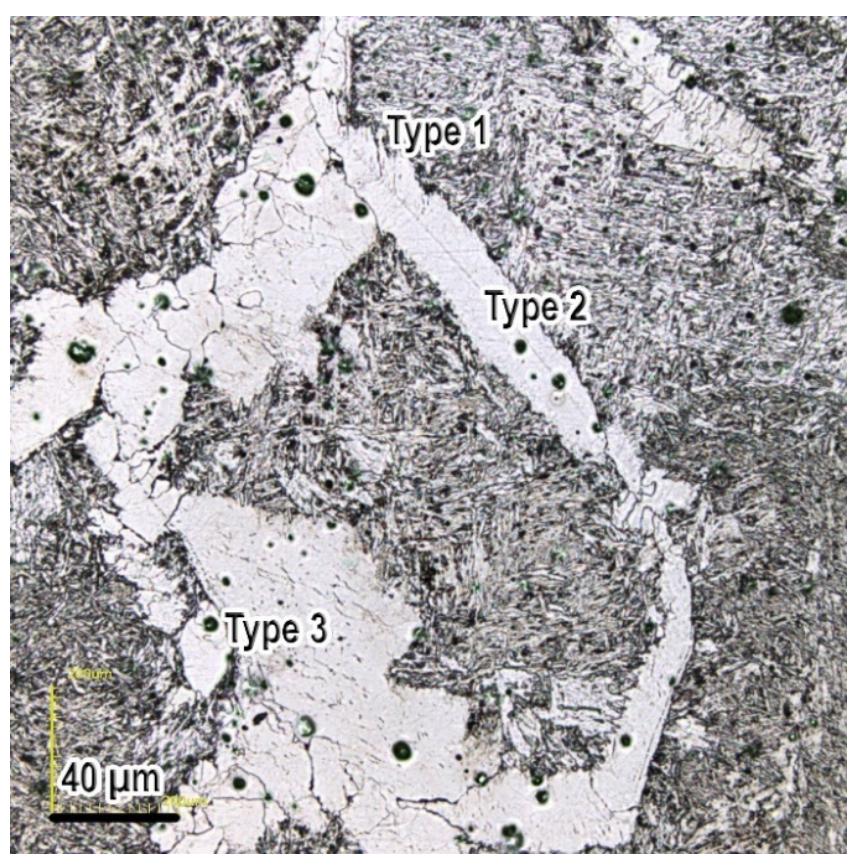

Figure 3. Micrograph of as-cast HSLA steel - precipitates types.

Figure 3 shows the morphology and the distribution of the main precipitates and inclusions found after the continuous casting process. Considering their location, they were classified into three types: located in the grain boundaries (type 1), aligned along the ferrite (type 2) and dispersed in ferrite grains (type 3 ) and non-metallic inclusions distributed heterogeneously in the microstructure. Figure 4 shows an illustration of the microstructure with the morphologies of the types of ferrite found in this condition and the classification of the precipitates. This microstructure was found to be similar to microalloyed steels and low cabon steel welded joints previously reported by Faria et al. (2019); Zhu et al. (2019), Hu et al. (2019).

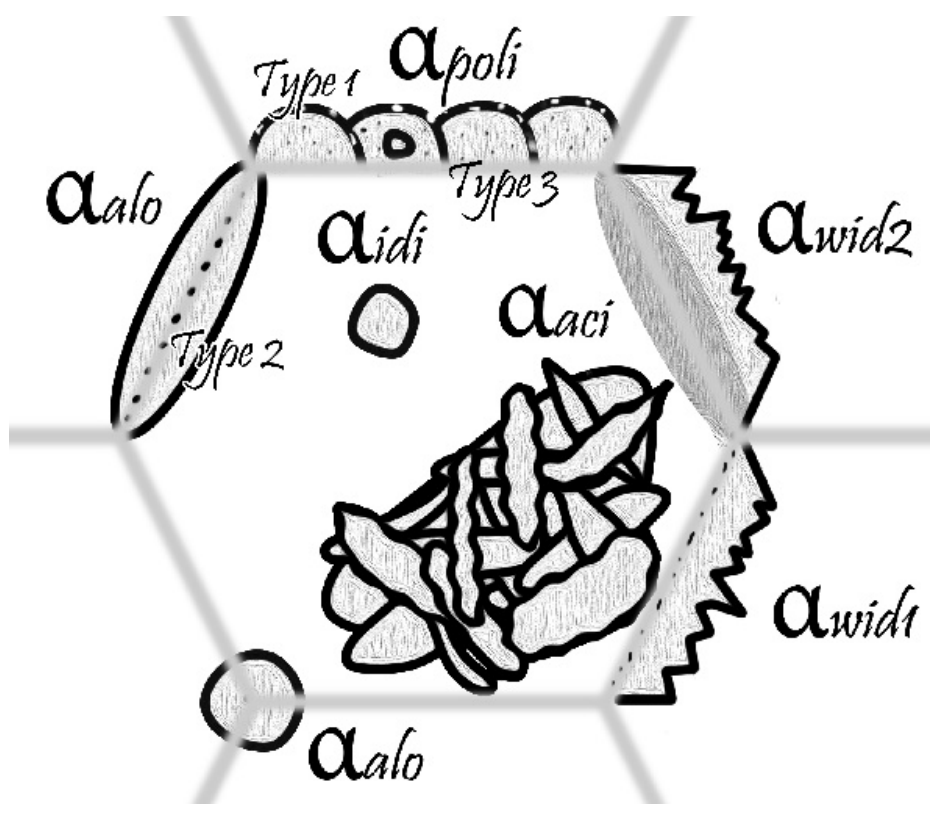

Figure 4. Illustration of the ferrite morphologies (types) and the location of the precipitates types of as-cast HSLA steel 
Figure 5 presents the micrograph of a region in which occurs the encounter of three polygonal ferrite grains. It can be observed the presence of precipitates aligned along each grain, indicating that they probably precipitate at primary austenite boundaries favored by the higher interface energy there.

The simple segregation of elements along the primary austenite grain boundaries may delay the intergranular nucleation. Edmonds et al. (2002) reported that the segregation of vanadium in this region causes the decrease of the interfacial energy between the precipitate and ferrite, once the solutes atoms in the boundaries reduce the disorder. Precipitation occurs preferentially in the boundaries, because the nucleation of these precipitates requires heterogeneous nucleation sites. Consequently, these precipitates may have favored the acicular ferrite nucleation, because the precipitate in the austenite boundary would be reducing the energy and occupying a favorable site to the intergranular nucleation of the bainite, whose nucleation occurs in the same temperature range of the acicular ferrite. It should still be considered that the inclusions and precipitates within the primary austenite grain may favor intragranular nucleation of acicular ferrite, as has already been shown by Barbaro (1989), Jin et al. (2008) and Zhang et al. (2018).

The micrographs from type 2 precipitates at points 1, 2 and 3 are shown in Figure 5. A high peak of Fe was verified because of the interaction of the electron beam with the metallic matrix. The peaks of the elements $\mathrm{Nb}$, $\mathrm{Cr}$ and $\mathrm{C}$ indicate that both precipitates are essentially niobium and chromium carbides. Niobium carbides and and niobium carbonitrides are responsible for the control of austenite grain growth, preventing or, at least, delaying the recrystallization of the austenite grains and, consequently, favoring products of lower transformation temperatures, such as acicular ferrite (Kuziak et al., 1995; Ma, 2008; Vervynckt, 2012; Zhao and Palmiere, 2018).
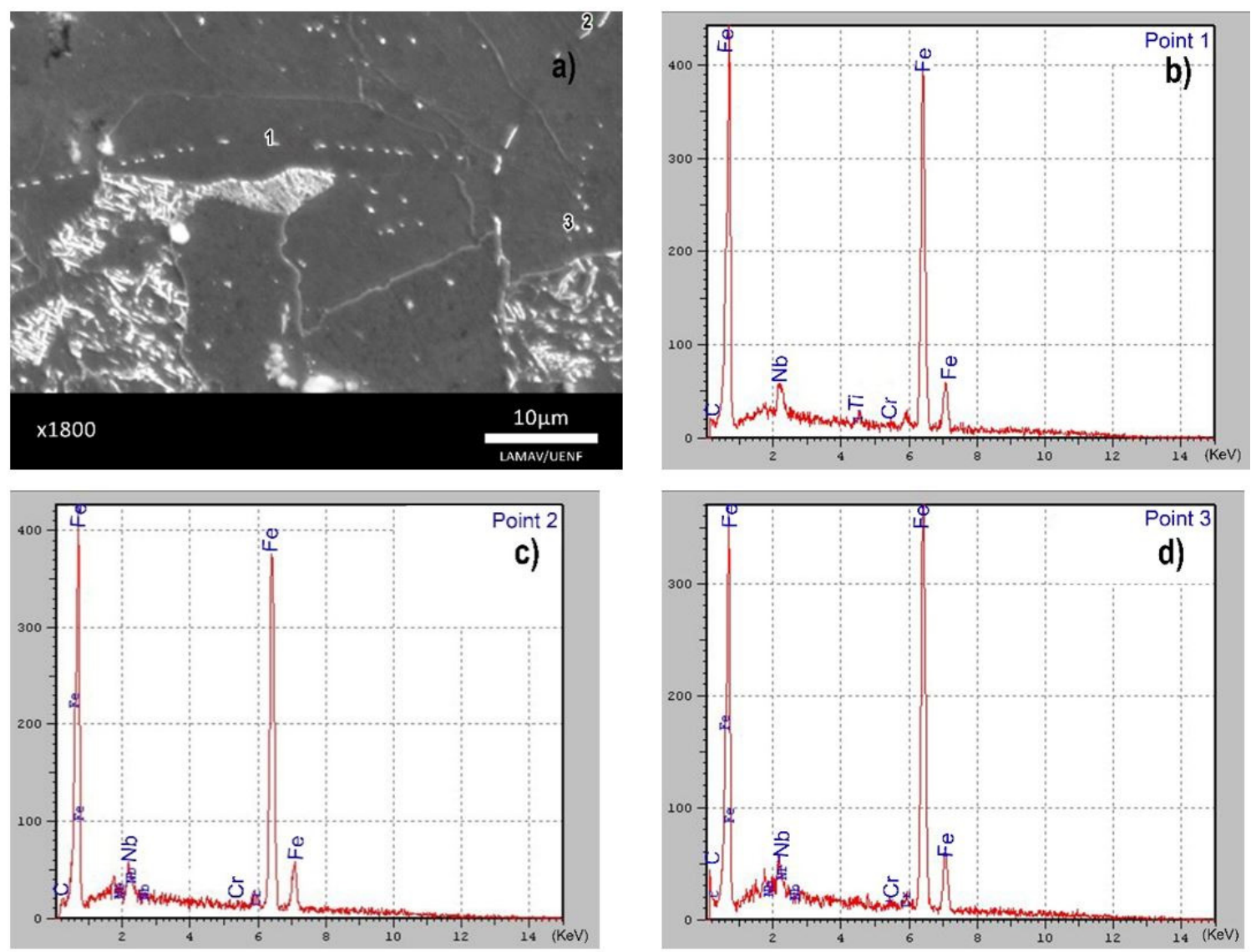

Figure 5. Micrography of the as-cast HSLA steel (a) and the respective EDS spectrum from points 1 (b), 2 (c) and $3(d)$.

In the research conducted by Crooks et al. (1981), the presence of niobium and vanadium carbonitrides in the boundaries of deformed primary austenite and other vanadium-rich precipitates possibly located at the interfaces of deformation bands was verified. 
Table 2 shows that the precipitates found in as-casted condition are mainly chromium and niobium carbides. In some of these precipitates, the presence of titanium was found. The distribution or location of each is given according to the classification presented in this paper.

Table 1. Classification, size and composition of precipitates found in as-cast condition

\begin{tabular}{ccc}
\hline Classification & Size $(\mu \mathrm{m})$ & Composition \\
\hline Type 3 & 0.42 & $\mathrm{C}, \mathrm{Nb}, \mathrm{Cr}$ \\
Type 2 & 0.45 & $\mathrm{C}, \mathrm{Nb}, \mathrm{Cr}$ \\
Type 2 & 0.78 & $\mathrm{C}, \mathrm{Nb}, \mathrm{Cr}$ \\
Type 2 & 0.9 & $\mathrm{C}, \mathrm{Nb}, \mathrm{Ti}, \mathrm{Cr}$ \\
Type 3 & 1.66 & $\mathrm{C}, \mathrm{Cr}$ \\
Type 2 & 1.85 & $\mathrm{C}, \mathrm{Nb}$ \\
\hline
\end{tabular}

In the SEM micrograph of Figure 6, two non-metallic inclusions were observed. The non-metallic inclusion indicated by point 1 presents acicular morphology, while points 3 and 2 indicate the center and the periphery of an inclusion non-metallic globular morphology, respectively. The spectrum of point 1 indicated that the particle is an inclusion of aluminum oxide. The particle of point 3 is an inclusion with complex composition. It is also observed that the periphery of the inclusion is mainly composed of $\mathrm{S}, \mathrm{Ca}$ and $\mathrm{Al}$, while the central region is mainly composed of $\mathrm{Al}, \mathrm{Ca}$ and $\mathrm{O}$.

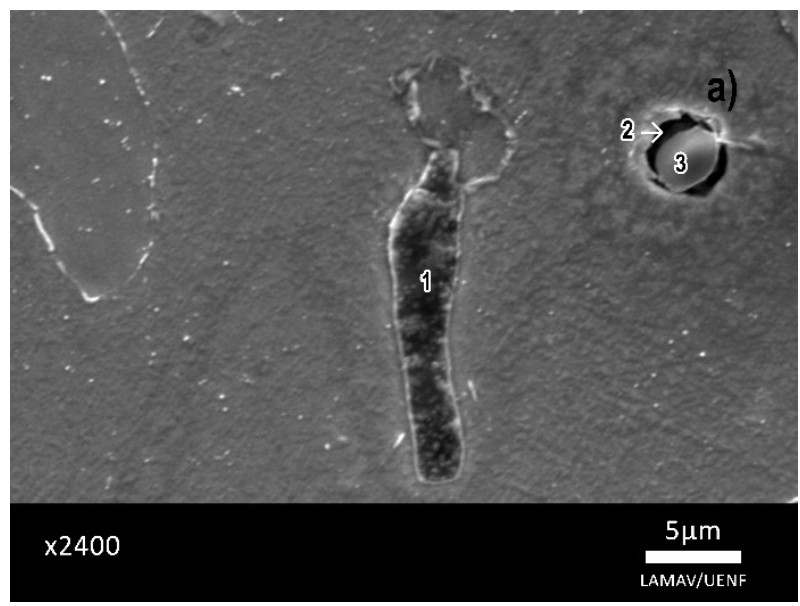

Figure 6. Microstructure of steel showing non-metallic inclusions

In the micrograph of Figure 7, three different inclusions marked by points 1-3 which contrast is quite similar, although the morphologies are different. The results of the EDS microanalysis of these points indicated that the marked particles by points 1 and 3 are aluminum oxide while particle of point 2 is an iron oxide.

Figure 8 shows inclusion classification according to main elements found in the EDS microalloalysis, morphology and size. In addition to these non-metallic inclusions, iron oxides were found. The calcium oxide inclusion particles with globular morphology have smaller size $(1.06-1.7 \mu \mathrm{m})$. The average size of the non-metalic inclusions found was $8.70 \mu \mathrm{m}$.

Probably the particles of group 1 with globular morphology are calcium aluminates. In these inclusions were also found other elements such as sulfur and phosphorus, which make the the composition more complex. Morphology indicates that calcium acted effectively on these particles, because according to Turkdogan (1996) and Shen and $\mathrm{Fu}$ (2019), this element is added to modify the morphology of aluminates and sulfides, making them more globular. Cicutti et al. (1997) and Ren et al. (2018) related that the morphology modification promoted by calcium is important to increase hydrogen-induced cracking resistance of pipelines. It is possible that these irregular shaped inclusion of groups 3,4 and 5 are respectively alumina, iron silicate, aluminates and 
silicates. Particles of group 3 also have polyhedral morphology. Athough the $\mathrm{Ca} / \mathrm{S}$ ratio is below 1.5 in this steel, which is it recommended for reduction in HIC occurrences, it was enough to modify the morphology of elongated MnS particles as they were not found. On the other hand, calcium content was not enough to modify the morphology of some aluminates.

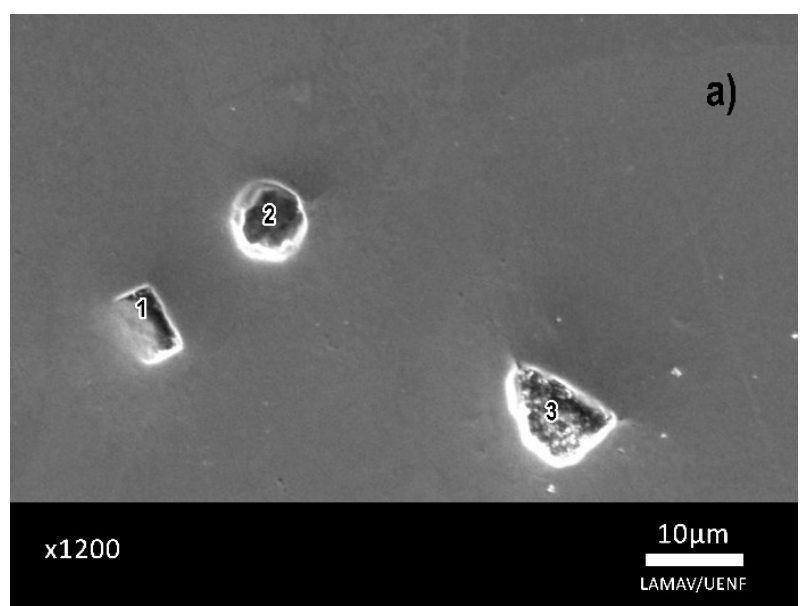

Figure 7. Particles with different morphologies

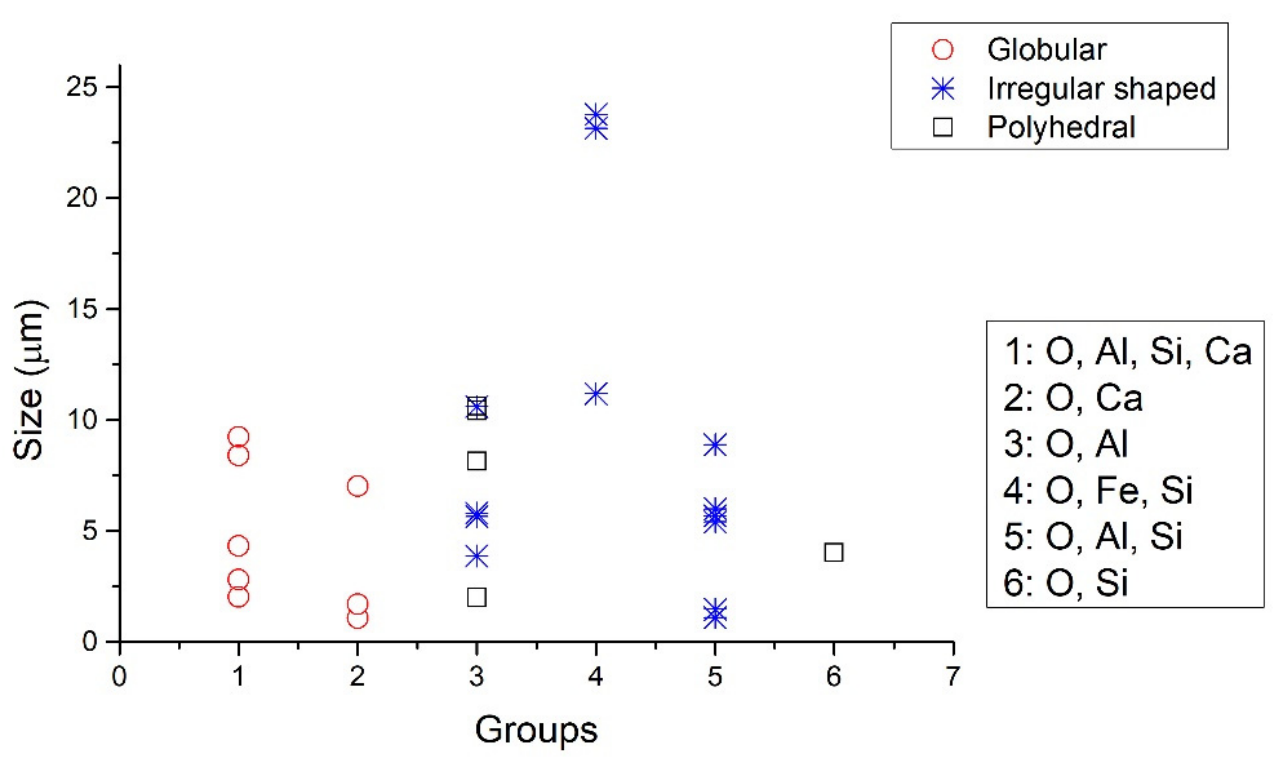

Figure 8. Size distribution of non-metallic inclusion according to morphology and composition.

\subsection{Annealed Condition}

Figure 9 revealed a biphasic microstructure formed mainly by polygonal grains of ferrite $\left(\alpha_{\text {poli }}\right)$ and carbides of iron aggregates and ferrite $\left(\alpha-\mathrm{Fe}_{3} \mathrm{C}\right)$, besides non-metallic inclusions and the aligned precipitates, which were found in the initial condition and remained stable due to their high dissolution temperature. The carbide and ferrite aggregates, also called degenerate pearlite, are often confused with bainite. Unfortunately, for steels with low carbon content, the recognition of these microconstituents is quite complex, once the formation of alternating lamellae of ferrite and cementite of pearlite is not possible due to the low carbon content.

The annealing temperature and the holding time used in the present work were sufficient for dissolution of the as-cast solidification structure. The microstructure of the steel, which consisted mainly of acicular ferrite and another ferrite types were modified to polygonal ferrite and pearlite, similar to that found in hypoeutectoid steels under metastable equilibrium. 


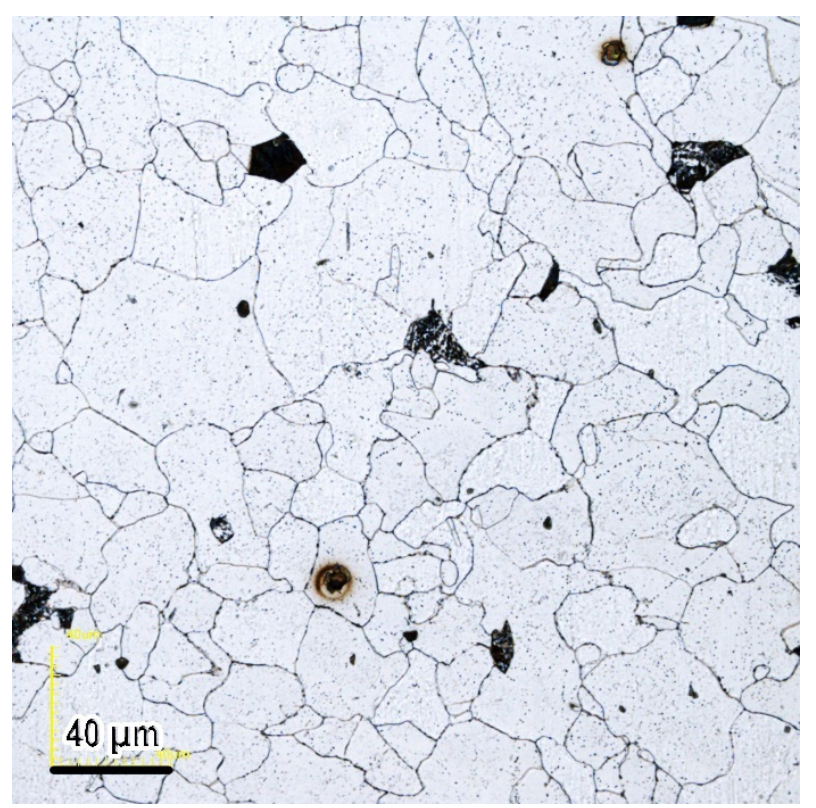

Figure 9. Microstructure of steel after annealing

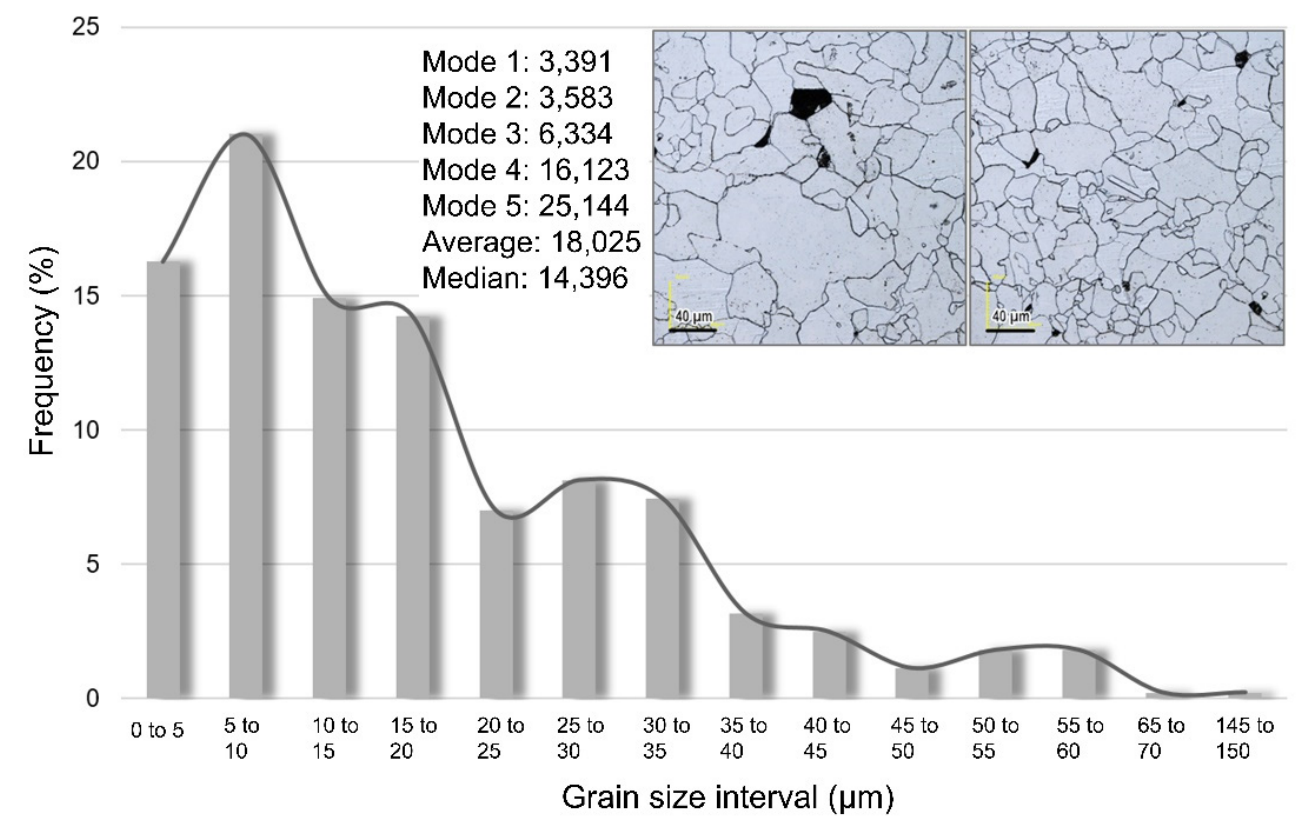

Figure 10. Histogram showing distribution of ferrite grain size in the annealed steel

The micrograph of Figure 11 shows the microstructure of the annealed sample comprising of polygonal grains of ferrite with the presence of aligned and dispersed precipitates in the boundariesas well as dispersed inside the ferrite grains.

Microstructures composed of ferrite and pearlite were also obtained after thermomechanical treatments of microalloyed steels. For microalloyed steels of different compositions, Tither et al. (1977) obtained, after homogenization at $1230^{\circ} \mathrm{C}$ and several hot rolling passes, a microstructure constitued of ferrite and degenerate pearlite, which they also called bainite. Arámburo et al. (2014) and Bakshi et al. (2019) also observed a similar microstructure in API X70 steel processed by controlled rolling. The main similarities between the microstructures obtained in the above-mentioned works are: the anisotropic structure and the average ASTM grain size of the ferrite between 9-10, both associated with the rolling process. 
The average grain size of the ferrite found was $18,03 \mu \mathrm{m}$, corresponding to an ASTM 9 grain size. In Figure 10, it is shown the histogram of the frequency of the ferrite grain size ranges found in annealed steel. It was observed a polymodal grain size distribution, which can be attributed to heterogeneous precipitation and pinning effect during heating. Truthfully, this can also be seen in the selected micrographs showed in the same figure. In contrast, Gomes et al. (2017) related that the presence of precipitates homogeneously distributed induce to uni-modal grain size distribution.

As it was observed, after the annealing treatment for 1 hour, the aligned precipitates found in the sample in the as-cast condition did not dissolve, indicating that your solubilization temperature is above $1100{ }^{\circ} \mathrm{C}$ (Irvine et al., 1967). The EDS point microanalysis was performed on 5 precipitates of Figure 11. The EDS spectrum from the points 1-3 showed that the aligned precipitates correspond to complex carbonitride precipitates of niobium, titanium and chromium. The particle from point 4 located inside the grain is a complex particle of calcium. EDS microanalysis were also performed on the precipitates located in the ferrite grain boundaries. By EDS microanalysis of point 5 , it was verified that they are essentially chromium carbides.

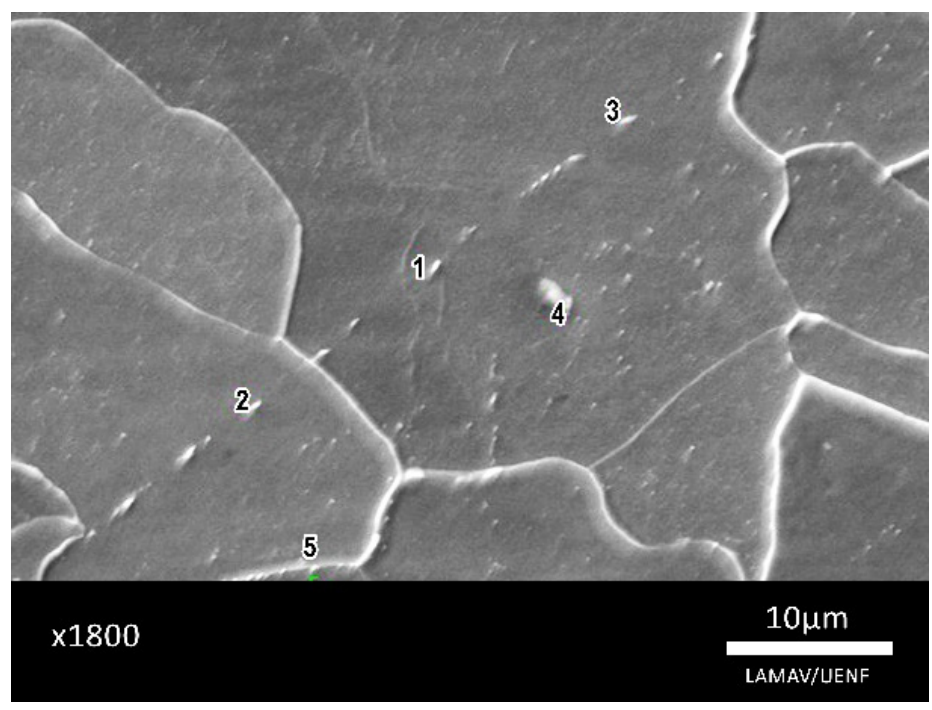

Figure 11. Ferrite grains and precipitates in annealed steel

Table 3 shows the size and composition of the precipitates found after annealing, as well as the classification according to their location. Titanium is present in almost all precipitates. In as-cast condition this element was found only in one of the precipitates analyzed. Niobium, titanium and niobium complex carbonitrides were also found, possibly the same as those previously found, but with the presence of other elements due to the diffusion promoted at the treatment temperature.

Table 2. Classification, size and composition of precipitates found in annealed condition.

\begin{tabular}{ccc}
\hline Classification & Size $(\mu \mathrm{m})$ & Composition \\
\hline Type 1 & 0.39 & $\mathrm{C}, \mathrm{Cr}$ \\
Type 3 & 0.47 & $\mathrm{C}, \mathrm{Nb}, \mathrm{Ti}$ \\
Type 2 & 0.66 & $\mathrm{C}, \mathrm{N}, \mathrm{Nb}, \mathrm{Ti}, \mathrm{Cr}$ \\
Type 2 & 0.86 & $\mathrm{C}, \mathrm{N}, \mathrm{Nb}, \mathrm{Ti}, \mathrm{Cr}$ \\
Type 2 & 1.05 & $\mathrm{C}, \mathrm{N}, \mathrm{Nb}, \mathrm{Ti}, \mathrm{Cr}$ \\
Type 3 & 1.31 & $\mathrm{C}, \mathrm{Nb}, \mathrm{Ti}, \mathrm{Cr}$ \\
Type 1 & 2.08 & $\mathrm{C}, \mathrm{Cr}$ \\
\hline
\end{tabular}




\subsection{Mechanical properties}

The mechanical properties obtained from tensile, hardness and impact tests are shown in Table 4. The as-cast HSLA steel has greater hardness and dispersion because of the presence of a heterogeneous microstructure. In addition to have provided a greater hardness, the microstructure constituted mainly by acicular ferrite and cementite resulted in higher yield stress and mechanical tensile strength.

Table 4. Mechanical properties of the steel in as-cast and annealed conditions

\begin{tabular}{lcc}
\hline \multicolumn{1}{c}{ Properties } & \multicolumn{2}{c}{ Condition } \\
& As-cast & Annealed \\
\hline Vicker Hardness (HV2) & $234 \pm 10$ & $120 \pm 3$ \\
Tensile Strength (MPa) & $589 \pm 50$ & $424 \pm 10$ \\
Yield Stress (MPa) & $336 \pm 30$ & $222 \pm 7$ \\
Ductility (\% Elongation) & $21 \pm 5$ & $36 \pm 2$ \\
Strain Hardening Expoent & 0,39 & 0,27 \\
Impact Energy Absorbed $(\mathrm{J})$ & $10 \pm 1$ & $348 \pm 3$ \\
\hline
\end{tabular}

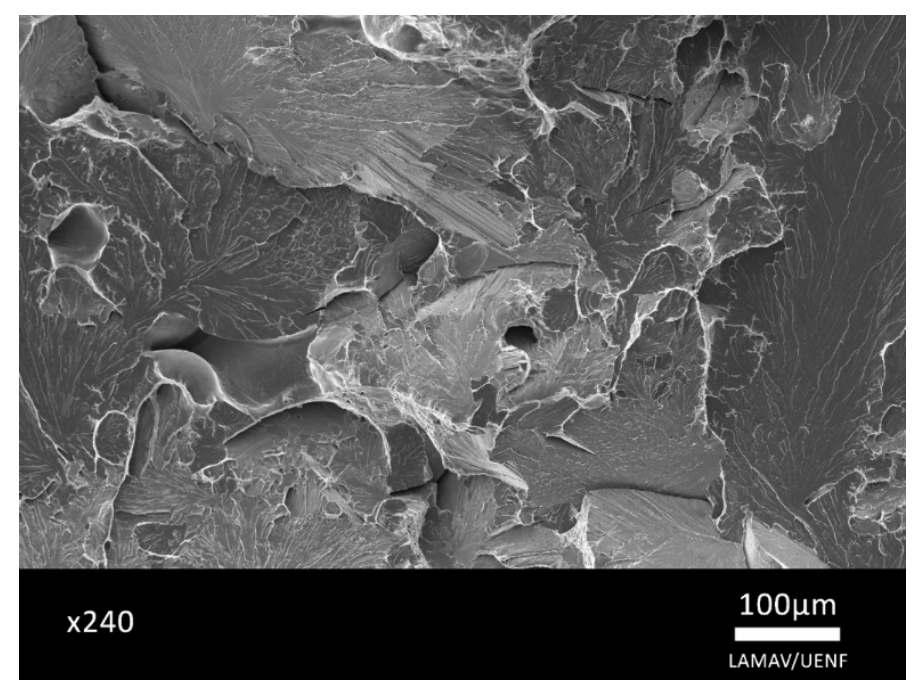

Figure 12. Charpy impact fractography of as-cast steel

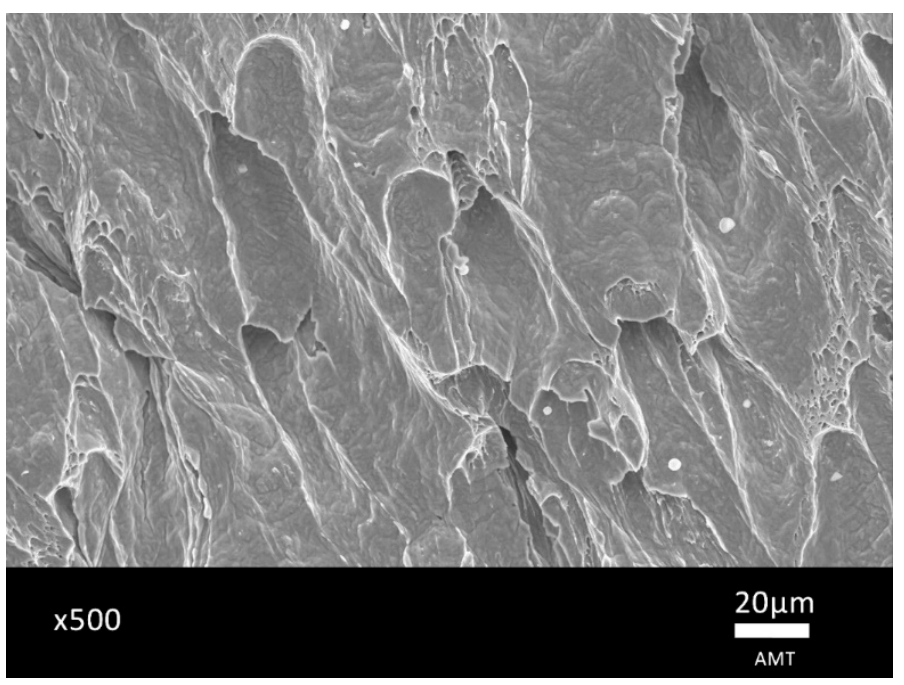

Figure 13. Charpy impact fractography of annealed steel 
The hardness of the alloy decreased after annealing, once all ferrite morphologies were converted to polygonal ferrite. However, due to the homogenization of the microstructure, the hardness dispersion was lower. An increase of the energy absorbed by the annealed steel was found in the Charpy impact test. The specimens of as-cast steel were completely fractured, while the same did not happen with annealed specimens. The fractographies of Charpy impact specimens of the steels under as-cast and annealed conditions are shown in Figures 12 and 13, respectively. The fracture process of the as-cast steel occurred through the formation of cleavage surface, containing river marks, while in the annealed steel fracture surface consisted of elongated microavoids of low depth, which indicate the occurrence of shear. Although a higher Charpy absorbed energy due to the higher volumetric fraction of acicular ferrite have been found in as rolled API X-70 steel by Shin et al. (2009), the presence of brittle constituents with lower resistance to crack propagation makes the steel in the as-cast condition very brittle, so that it is less ductile also during tensile testing.

\section{Conclusions}

The annealing treatment at $1100{ }^{\circ} \mathrm{C}$ for 1 hour eliminated the as-cast microstructure. After this heat treatment, the microstructure, which was mainly composed of acicular ferrite, became predominantly polygonal ferrite and ferrite and carbide aggregates (pearlite) and some particles dissolved. The heterogeneous distribution of precipitates was responsible for the polymodal distribution of grain size.

In the studied conditions, three types of precipitates were classified according to their distribution in the microstructure: 1) located in the boundaries of the grains, 2) aligned along the ferrite and 3) dispersed within the polygonal ferrite grains. From the EDS microanalysis these precipitates were identified mainly carbides and carbonitrides of chromium and niobium with the presence of other elements such as titanium. Globular non-metallic inclusions of calcium oxide and also calcium aluminate was found, but calcium content was not enough to modify the morphology of some aluminates.

In as-cast condition, steel showed highest hardness and mechanical strength, but lower ductility. Although both contidion have close tensile strength, the energy absorbed during impact was higher in the annealed sample. Because of this brittle behavior, the steel could not be used in as-cast condition. The annealing carried out showed to be appropriate in different aspects, so that the annealing temperature can be used as the soaking temperature before the forming process. However, it should also be considered that the grain size distribution found may be detrimental and that the austenite transformation products during the forming process will be probably modified by the parameters of the thermomechanical process, such as temperature of strain and cooling rate.

\section{Acknowledgments}

The authors gratefully acknowledge the financial support provided by FAPERJ (Rio de Janeiro State Foundation for Research Support)

\section{References}

American Petroleum Institute - API (2013). ANSI/API Specification 5L: Specification for line pipe. Washington: API Publishing Services.

American Society for Testing and Materials - ASTM. E8. (2015). Standard test methods for tension testing of metallic metals. Philadelphia: ASTM.

American Society for Testing and Materials - ASTM. E23. (2013). Standard test methods for noched bar impact testing of metallic metals. Philadelphia: ASTM.

Arámburo, G., García, S., Pérez, R., \& Juárez, J. A. (2004). Impacto tecnológico de aceros grado API 5L X-70 para la fabricación de ductos de 36 de diámetro resistentes al gas amargo. Ingeniería. Investigación y Tecnología, (1), 17-26.

Babu, S. S., \& Bhadeshia, H. K. D. H. (1991). A direct study of grain boundary allotriomorphic ferrite crystallography. Materials Science and Engineering: A, 142(2), 209-219.

Bakshi, S. D., Dhande, T., Javed, N., Sasidhar, K. N., Sharma, V., Mukherjee, M., Gosh, B., \& Mahashabde, V. V. (2019). Effect of hot deformation and crystallographic texture on toughness anisotropy and fracture behavior of $\mathrm{Nb}+\mathrm{V}$ microalloyed API X70 steel. International Journal of Pressure Vessels and Piping, 171, $162-172$.

Barbaro, F. J., Krauklis, P., \& Easterling, K. E. (1989). Formation of acicular ferrite at oxide particles in steels. Materials science and technology, 5(11), 1057-1068. 
Basanta, G.; Rivas, A; Ruiz, A. (2011). SEM Characterization Of Complex Precipitates In An As-Cast Nb-V-Ti Microalloyed Steel. Revista Latinoamericana de Metalurgia y Materiales, 31(2), 138-144.

Cicutti, C. E., Madias, J., \& Gonzalez, J. C. (1997). Control of microinclusions in calcium treated aluminium killed steels. Ironmaking \& steelmaking, 24(2), 155-159.

Crooks, M. J., Garratt-Reed, A. J., Vander Sande, J. B., \& Owen, W. S. (1981). Precipitation and recrystallization in some vanadium and vanadium-niobium microalloyed steels. Metallurgical Transactions A, 12(12), 1999-2013.

Davis, J.R. (2001). Alloying: understanding the basics. Materials Park: ASM International.

Faria, B. C., Oliveira, B. F., \& da Silva, S. E. T. P. (2019). Análise de Falha e do Projeto Construtivo de um Vaso de Pressão. Perspectivas Online: Exatas \& Engenharia, 9(24) (In Portuguese).

Gomes, É. F. R., Lessa, M. A. L. V. H., Lourenço, M. D. R. R., \& de Oliveira, B. F. (2017). Efeito da Temperatura de Recozimento sobre a microestrutura e as Propriedades Mecânicas do Aço ARBL Microligado NBR 6656 LNE 380. Perspectivas Online: Exatas \& Engenharia, 7(18) (In Portuguese).

Ghosh, G., Rostron, P., Garg, R., \& Panday, A. (2018). Hydrogen induced cracking of pipeline and pressure vessel steels: A review. Engineering Fracture Mechanics, 199, 609-618.

He, K., \& Edmonds, D. V. (2002). Formation of acicular ferrite and influence of vanadium alloying. Materials science and technology, 18(3), 289-296.

Holappa, L., Hämäläinen, M., Liukkonen, M., \& Lind, M. (2003). Thermodynamic examination of inclusion modification and precipitation from calcium treatment to solidified steel. Ironmaking \& steelmaking, 30(2), 111-115.

Irvine, K. J., Pickering, F. B., \& Gladman, T. (1967). Grain-refined C-Mn steels. Iron Steel Inst J, 205(2), 161-182.

Jin, H. H., Shin, C. S., \& Lee, H. C. (2008). Effect of Vanadium on Development of Acicular Ferrite Microstructure in Low Carbon Steel. In Solid State Phenomena, 135, 111-114.

Kim, Y. M., Shin, S. Y., Lee, H., Hwang, B., Lee, S., \& Kim, N. J. (2007). Effects of molybdenum and vanadium addition on tensile and charpy impact properties of API X70 linepipe steels. Metallurgical and Materials Transactions A, 38(8), 1731-1742.

Kuziak, R., Bołd, T., \& Cheng, Y. W. (1995). Microstructure control of ferrite-pearlite high strength low alloy steels utilizing microalloying additions. Journal of Materials Processing Technology, 53(1-2), 255-262.

Lee, T. K., \& HJ, K. (2000). Effect of inclusion size on the nucleation of acicular ferrite in welds. ISIJ international, 40(12), 1260-1268.

Loder, D., Michelic, S. K., \& Bernhard, C. (2017). Acicular ferrite formation and its influencing factors-A review. J. Mater. Sci. Res, 6(1), 24-43.

Ma, L., Wang, M. Q., Shi, J., Hui, W. J., \& Dong, H. (2008). Influence of niobium microalloying on rotating bending fatigue properties of case carburized steels. Materials Science and Engineering: A, 498(1-2), 258-265.

Ren, X., Fu, H., Xing, J., Tang, S., \& Zhang, Q. (2018). Effect of calcium modification on solidification, heat treatment microstructure and toughness of high boron high speed steel. Materials Research Express, 6(1), 016540 .

Shen, P., \& Fu, J. (2019). Morphology Study on Inclusion Modifications Using Mg-Ca Treatment in Resulfurized Special Steel. Materials, 12(2), 197.

Shin, S. Y., Woo, K. J., Hwang, B., Kim, S., \& Lee, S. (2009). Fracture-toughness analysis in transition-temperature region of Three American Petroleum Institute X70 and X80 pipeline steels. Metallurgical and Materials Transactions A, 40(4), 867-876.

Tisza, M. (2002). Physical metallurgy for engineers. London: ASM International and Freund Publishing House Ltd.

Tither, G., \& Lauprecht, W. E. (1977). Pearlite-reduced HSLA steels for line pipe. Metal Science and Heat Treatment, 19(7), 543-555.

Turkdogan, ET. (1996). Fundamentals of Steelmaking. London: Maney Materials Science. 
Vervynckt, S., Thibaux, P., \& Verbeken, K. (2012). Effect of niobium on the microstructure and mechanical properties of hot rolled microalloyed steels after recrystallization-controlled rolling. Metals and Materials International, 18(1), 37-46.

Xu, Z. Y., Liu, J. H., He, Z. J., \& Pang, Q. H. (2018). Study on clogging mechanism of submerged entry nozzle of steel 38CrMoAl. Metalurgija, 57(1-2), 79-82.

Wu, C. P. P. (2009). Inclusion Characterization in High Strength Low Alloy Steel (Master thesis). University of Toronto, Canada.

Zhang, C. J., Gao, L. N., \& Zhu, L. G. (2018). Effect of inclusion size and type on the nucleation of acicular ferrite in high strength ship plate steel. ISIJ International, 58(5), 965-969.

Zhao, H., \& Palmiere, E. J. (2018). Effect of austenite grain size on acicular ferrite transformation in a HSLA steel. Materials Characterization, 145, 479-489.

Zhao, H., Wynne, B. P., \& Palmiere, E. J. (2018). Conditions for the occurrence of acicular ferrite transformation in HSLA steels. Journal of materials science, 53(5), 3785-3804.

Zhu, L., Wang, Y., Wang, S., Zhang, Q., \& Zhang, C. (2019). Research of microalloy elements to induce intragranular acicular ferrite in shipbuilding steel. Ironmaking \& Steelmaking, 46(6), 499-507.

\section{Copyrights}

Copyright for this article is retained by the author(s), with first publication rights granted to the journal.

This is an open-access article distributed under the terms and conditions of the Creative Commons Attribution license (http://creativecommons.org/licenses/by/4.0/). 